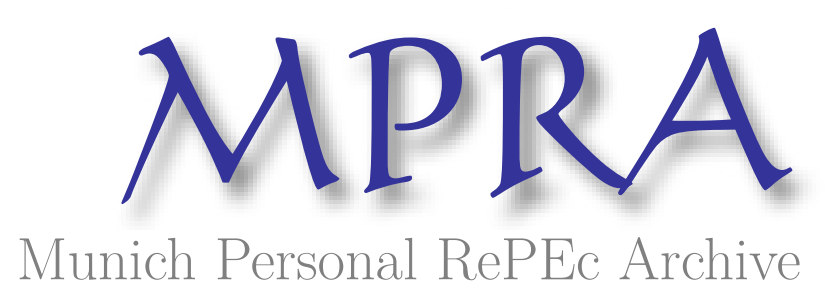

\title{
Trade finance and international currency
}

Liu, Tao

University of California, Davis

14 May 2015

Online at https://mpra.ub.uni-muenchen.de/64362/

MPRA Paper No. 64362, posted 15 May 2015 13:28 UTC 


\title{
Trade Finance and International Currency
}

\author{
Tao Liu* \\ Preliminary and Incomplete
}

May 14, 2015

\begin{abstract}
The determinants of international currency received a lot of academic attention since great recession, especially given China's intention to internationalize RMB. Recent empirical studies in history and international economics confirmed the importance of financial market development in this process. To provide micro-foundation for such observation, I built a two-country monetary search model with financial friction. Trade takes a long time, and the lack of trust makes importer and exporter rely on bank-intermediated finance. The choice of international currency is related with terms of trade, monetary policy, and financial market development. The effect of monetary policy on international trade differs according to currency regime. Related topic such as size effect and capital account liberalization is also discussed.
\end{abstract}

*I'm indebted to Wing Woo for continuous guidance and support. I also thank Athanasios Geromichalos, Seungduck Lee, and Mingzhi Xu for helpful comments and suggestions. 


\section{Introduction}

The international monetary system came under serious doubt after the global financial crisis in 2008. Many alternatives have been proposed to replace the exorbitant privilege of US dollar, such as SDR (Zhou, 2009), a multipolar system (Eichengreen, 2011), and a single world currency (Mundell, 2012). Beyond the political implication of such a dramatic power shift, it's economically interesting to consider the determinants of international currency, especially the rise-up of a previously national currency and the possibility of multiple international currencies.

Here international currency is defined as a fiat money not only circulating in its home country but also held by foreigners. As a store of value, it could be government's international reserve or private person's investment instrument. As a medium of exchange, it could smooth central bank's foreign exchange intervention or facilitate international trade. As a unit of account, it would denominate international transactions or become the anchor of other currencies. Table 1 summarized these functions. This paper is mainly concerned with medium of exchange as the function of international currency.

Academic research traditionally focused on economy of scale and path dependence in the evolution of international currency (e.g., Krugman, 1979, Rey, 2001). In this view, size effect is important since large trade volume helps reduce transaction cost. The status of international currency therefore requires a large economy and huge volume of international trade. The size effect also ensures path dependence and incumbency advantage so that, once a currency becomes international, people would have no incentive of deviation.

Historical experience, however, shows another picture. US GDP surpassed Great Britain in 1870s, and US share of world export surged from $14.1 \%$ in 1872 to $22.1 \%$ in 1913, but the international role of US dollar was essentially zero while Sterling is estimated to have invoiced over $60 \%$ of world trade by early twentieth century (Broz, 1997). Similarly, China became the leader of international merchandise trade in 2013 by WTO estimation, but its currency remains national. The advantage of incumbency is also open to question. Eichengreen and Flandreau (2012) showed that US dollar and sterling shared the status of international currency as early as 1920s. 
Recent literature used new dataset to emphasize the importance of financial development. One leading research is Ito and Chinn (2013) that empirically documented the relationship between capital account liberalization and trade invoice currency, attributing RMB's low degree of internationalization to the drawback of its financial system.

This paper tries to provide micro-foundation for such observation and discuss monetary policy in different currency regimes. To that end, I incorporated financial friction into the two-country model in Zhang (2014). In my model, trade takes a long time, and agents disagree on the timing of shipment and payment, so they rely on bank-intermediated finance. Agent's choice of international currency is related with terms of trade, monetary policy, and financial market development. Three currency regimes naturally arise: single international currency, producer currency pricing (PCP), and local currency pricing (LCP). The impact of monetary policy on trade and welfare would differ according to currency regime.

This paper also follows a long tradition of explicitly modeling bank and credit since Diamond and Dybvig (1983). One difficulty in this field is that, as pointed out by Berentsen et al. (2007), there must be an absence of record keeping for money to be essential, but credit requires record keeping in case of default. The inherent tension between money and credit is not present in this model thanks to the institutional setup of trade finance: importer has no incentive to default since that would make him lose the ownership of goods purchased from exporter. Money could coexist with credit in an environment without record keeping, and credit improves welfare by facilitating trade.

The rest of this paper proceeds as follows. Part 2 reviews economic literature on international currency. Part 3 documents the practice of trade finance, especially the mechanism of letter of credit. Part 4 describes model environment and defines monetary equilibrium. Part 5 undergoes discussion on related topic with numerical example. Part 6 concludes. 


\section{Literature review}

Academic research on international currency spans economics and politics. Interested reader could refer to Bénassy-Quéré (2015) for a systematic review. This section is focused on economic theories that regarded international currency as the outcome of decentralized choice by private sector.

\section{$2.1 \quad$ Trade model}

This strand of literature mostly used a general equilibrium model of 3-country or $\mathrm{N}$-country to explain the phenomenon of international vehicle currency (for example, Krugman, 1979; Rey, 2001; Devereux and Shi, 2013). International vehicle currency (IVC) is issued by (say) country A but used in the bilateral trade between country B and C. In these models, producer and consumer hold only home currency, and foreign exchange transaction is undertaken by financial intermediary or trading post, which has an increasing-return-to-scale technology that lowers transaction cost with a large trade volume. With the assumption of cash in advance and PCP, agent's choice of invoicing currency is exogenously given. The existence of a general equilibrium with IVC is crucially dependent on economic openness. Therefore, the currency issued by a country intensively engaged in international trade would emerge as IVC. This thick market or network externality also makes the status of IVC a natural monopoly that secures path dependence. The advantage of such model comes from its nature of general equilibrium: the welfare gain of using IVC could be analyzed, and discussion of monetary policy is feasible. An obvious drawback is the lack of micro-foundation. The choice of invoicing currency is exogenous, so it's impossible to explain the rise and fall of different currency regimes.

\subsection{Micro-structure model}

With the increasing data availability at firm and industry level, a microeconomic theory of invoicing currency prospers in recent years. Bacchetta and Van Wincoop (2005) showed that producer's invoicing choice is affected by competition in foreign markets: higher level of exporter's market share and differentiation tends to promote 
PCP. Goldberg and Tille (2008) continued this approach and showed that producers in industries with hight demand elasticities are more likely to herding in the choice of invoicing currency, which was verified by a dataset of 24 countries. Another approach is in Goldberg and Tille (2013), where the choice of invoicing currency is solved in a Nash bargaining game between exporter and importer, and the outcome is related with elements of market structure such as fragmentation, heterogeneity, and risk tolerance. For all its significance and excellency, micro-structure model is not explicit about the underlying process of currency circulation and exchange. Producer's choice mainly reflects uncertainty of demand and exchange rate. In addition, most of these models are partial equilibrium, making it improper for welfare analysis and policy discussion.

\subsection{Search model}

Search theory is seemingly born to discuss the determinants of international currency, with its inherent advantage in answering why fiat money circulates as medium of exchange. Earlier studies of first-generation theory employed two-country two-currency model, but suffered from the indivisibility of output and money, as in Matsuyama et al. (1993). Second-generation theory endogenized output by bargaining, as in Trejos and Wright (1996), but still couldn't reach equilibrium.

With the breakthrough in Lagos and Wright (2005), search theory is now widely applied to topics in international macroeconomics. This paper is closest in methodology to Zhang (2014), who used an information-based theory to discuss the determinants of international currency and its implication for monetary policy, but my approach is different in several ways. First, there is an additional round of financial market since exporter and importer rely on bank-intermediated finance for trade settlement. Second, the cost of using a certain currency comes from the fixed cost in banking sector, which is more realistic than information cost. This means home currency use is also costly, so agents make a binary choice of using home or foreign currency, and distinct currencies are longer perfect substitutes. Lastly, the role of government is not explicitly stipulating home currency use. Instead, it would decide on whether to absorb the initial cost of financial market and make its own currency 
international.

\section{International trade finance}

The timing of payment and delivery is always a big issue for international trade. Without mutual trust or history record, the direct and bilateral trade between buyer and seller would bring in a lot of uncertainty: buyers don't know whether they could get goods after payment, and sellers are not guaranteed that they would get paid after delivery. According to the timing of payment and delivery, the pattern of trade finance could be generally classified into three groups: Cash-in-advance (payment before delivery), Open account (payment after delivery), and Bank trade finance. If buyer and seller trust each other, cash-in-advance or open account would be a good choice with a relatively low transaction cost. If sellers don't trust buyer but believe the credit of buyer's bank, bank-intermediated trade finance would come into play. Figure 1 gives a snapshot of the share of different trade finance during 2008-09 financial crisis.

It should be noted that there is no comprehensive measure of trade finance, and most data in this field are either estimation or based on survey report. Despite the limited data availability, it's safe to conclude that bank trade finance is important in facilitating international trade, although its contribution varies in different estimation. For bank trade finance, the most important instrument is Letter of Credit (LC). Committee on the Global Financial System (2014) estimated that bank trade finance directly supports about one-third of global trade, with LC covering about one-sixth of total trade. International Chamber of Commerce (ICC, 2014) has a similar conclusion on the importance of LC in bank trade finance: in 2013, the share of traditional commercial LC in export and import trade finance is $41 \%$ and $36 \%$. Not very surprisingly, this number has a great variation across region and nation. ICC Banking Commission (2014) reported that Europe and North America used more of Document Collection (DC), while Asia-Pacific countries heavily rely on LC, covering $75 \%$ and $68 \%$ of their export and import bank trade finance. Niepmann and Schmidt-Eisenlohr (2014) empirically studied LC in United States, finding that LC only covers $8.8 \%$ of U.S. export in 2012, though with different degrees across country and industry, vary- 
ing between 0 and $90 \%$. For example, $30 \%$ of U.S. export to China is financed by LC. According to Niepmann and Schmidt-Eisenlohr (2014), the use of LC is highly correlated with contract environment and rule of law: LC are employed the most for exports to countries with intermediate degrees of contract enforcement. LC is also used for riskier destinations than DC. In short, LC plays an important role in trade finance, especially for developing and Asia-Pacific countries. The next part would show the basic mechanism of LC.

\subsection{Letter of credit step by step}

Figure 2 shows the working mechanism of LC. The following step of LC is in order.

Step 1 Exporter and importer would determine terms of trade and sign a business contract.

Step 2 Importer would go to issuing bank, show the contract, and apply for LC. The issuing bank would ask for a certain amount of collateral from importer, ranging from $100 \%$ to $5 \%$ of the total payment.

Letter of credit is "a commitment by a bank on behalf of the buyer that payment would be made to the beneficiary provided that the terms and conditions stated in LC has been met, consisting of the presentation of specified documents" (U.S. department of commerce). The issuing bank would make a payment only a certain days after shipment, and that's the maturity of LC, usually less than 6 months.

Step 3 The issuing bank would issue LC and sent it to advising bank for scrutiny

Step 4 After checking the details, advising bank would notify exporter so that he could prepare shipment.

Step 5 Exporter make shipment and get the required document, especially bill of lad$\operatorname{ing}(\mathrm{B} / \mathrm{L})$. 
Bill of lading is a document issued by carrier which details a shipment of merchandise and gives title of that shipment to a specified party, usually its holder.

Step 6 Exporter send required document to advising bank for payment.

Step 7 After checking the required document, advising bank would notify the issuing bank. In principle, exporter need to wait until maturity of LC, but he is usually in urgent need of liquidity, so advising bank would make payment to exporter at discount.

Step 8 The principle of "borrow short and lend long" makes advising bank unwilling to hold LC, given that its maturity is less than 6 months. Advising bank would sell $\mathrm{LC}$ and other required documents to anyone interested in short-term investment.

The set of documents including $\mathrm{LC}$ and $\mathrm{B} / \mathrm{L}$ is referred to as trade acceptance, whose payment is guaranteed by both issuing bank and advising bank. So trade acceptance is a very safe short-term bond.

Step 9 At the time of maturity, anyone holding trade acceptance could go to issuing bank for payment. After double-checking the required document, issuing bank would notify importer. The importer would then make payment and get shipment of goods.

Several comments on LC. First, it's obvious from the elaborate description that issuing LC is quite labor-intensive and would incur a large fixed cost for bank, which is confirmed in Niepmann and Schmidt-Eisenlohr (2014) reporting that the top 5 U.S. bank in this field accounted for more than $92 \%$ of LC claims. Second, buyer would not want to default in this contract environment since he couldn't get shipment of goods without payment. The actual default rate of LC reported in ICC Banking Commission (2014) is $0.033 \%$ for export and $0.117 \%$ for import. Lastly, the currency denominating LC should have a liquid financial market and low transaction cost so that sellers could be easily financed. Actually US dollar is still dominant in LC, making up $82 \%$ in total value (ICC Banking Commission, 2014), but the recent riseup of RMB is also noteworthy, compromising around $9 \%$ of total value. 


\section{The Model}

\subsection{Environment}

Time is discrete and infinite. There are two countries in the world, 1 and 2, each populated with a unit measure of buyer, seller, and investor, who live forever with a discount factor of $\beta \in(0,1)$. Their identity is fixed over time and their respective population is $\sigma, \sigma$, and $(1-2 \sigma)$. In addition, each country has a perfect competitive banking sector. Each period is divided into three rounds of centralized market (CM), decentralized market (DM), and financial market (FM). There is divisible and storable fiat money circulating in each country, and its total supply evolves according to $\hat{M}_{i}=\left(1+\mu_{i}\right) M_{i}$, where $M_{i}$ is the stock of country i's fiat money in current period, and variable with a hat is the level in next period. The growth rate of money supply, $\mu_{i}$, is under the control of central bank.

Here I start with brief introduction on model, and a formal description would follow. In DM, sellers are specialized in the production of a perishable differentiated good $q$ but unable to consume it, while buyers are able to consume but couldn't produce. Due to imperfect credit and lack of record, a medium of exchange is necessary. Moreover, $q$ is delivered only at the beginning of next period, and buyers promise to make payment then. Assume agents from different countries don't trust each other, so international trade settlement is facilitated by bank-intermediated finance. After shipment, sellers get immediate liquidity from banking sector at discount. In FM, investors could purchase trade acceptance from banks. Here trade acceptance is equivalent to a one-period nominal bond whose supply is based on buyer's future payment. At the beginning of next period, buyers make payment to get $q$, and investors receive payoff for their holding of trade acceptance. In the following $\mathrm{CM}$, buyer, seller, and investor engage in the production of a perishable numéraire good $X$ and adjust their holdings of fiat money. The time-line is depicted in figure 3.

Now I will begin to formalize the setup of physical environment. For tractability, assume the instantaneous utility function for buyer, seller, and investor in two 
countries is the following

$$
\begin{aligned}
& U^{B}=u(q)+U(X)-H \\
& U^{S}=-c(q)+U(X)-H \\
& U^{I}=U(X)-H
\end{aligned}
$$

where q, X, and H capture the amount of specialized good, numéraire good, and working hour. While every agent could produce numéraire good with a linear technology of $X=H$, only sellers could produce differentiated good at the cost of $c(q)$. It's further assumed that the optimal consumption in CM is $X^{*}$, such that $U^{\prime}\left(X^{*}\right)=1$. The conventional assumption on function form also holds, so $u(0)=c(0)=0, u^{\prime}(0)=$ $+\infty, c^{\prime}(0)=0, u^{\prime}>0, u^{\prime \prime}<0, c^{\prime}>0, c^{\prime \prime}>0$. For notations below, $i=\{1,2\}$, $j=\{1,2\} \neq i$. The real value of country i's fiat money in terms of numéraire good is $\phi_{i}$. This model is focused on stationary monetary equilibrium where the aggregate real balance is constant, therefore $1+\mu_{i}=\frac{\phi_{i}}{\hat{\phi}_{i}}$. Central banks adjust home currency supply through lump-sum transfer to domestic agent when CM opens.

There is separate DM in each country. Buyers could go abroad with a probability of $(1-\alpha)$ while sellers stay at home. Buyer and seller meet pairwise and at random, with a matching function of $N_{i}=\frac{B_{i} S_{i}}{B_{i}+S_{i}}$, where $N_{i}$ is the number of successful matching in country i, with $B_{i}$ and $S_{i}$ for the number of buyer and seller in country i's DM. With this matching function, the number of meeting between country $\mathrm{i}$ buyer and country $\mathrm{j}$ seller $\left(n_{i j}\right)$, as well as the probability for country i buyer to meet country $\mathrm{j}$ seller $\left(p_{i j}\right)$ could be determined. DM in this model functions as international trade market. FM is segmented by capital control. The banking sector in country i could issue LC denominated in its home currency. The total cost $\left(F_{i}\right)$ is assumed to be fixed to reflect economy of scale. $F_{i}$ is also a proxy for financial development. FM in this model represents financial market for short-term investment.

In contrast, CM is open to buyer, seller, and investor from both countries. This Walrasian market allows agents to adjust their holding of home and foreign currency, 
so it's similar to a frictionless foreign exchange market ${ }^{1}$. Additionally, since central bank's lump-sum transfer is only for domestic agents, extracting seigniorage revenue through inflation is possible only when a certain currency is demanded by foreigners.

The currency regime is endogenized by seller's binary choice of settlement currency 2. If financial frictions make international trade unprofitable, international currency would never emerge. Otherwise, sellers would choose whichever currency that brings a higher level of profit.

\subsection{Optimal choice and equilibrium}

\subsubsection{Value function}

Agent's CM value function differs according to his type. For buyer, he would want to hold money at the end of CM to enjoy differentiated good in next period, therefore the CM maximization problem for buyer in country i is

$$
\begin{gathered}
W_{i}^{B}\left(\phi_{i} m_{i}^{i}, \phi_{j} m_{j}^{i}\right)=\max _{\hat{m}_{i}^{i}, \hat{m}_{j}^{i}, H, X} U(X)-H+\beta \mathbb{E}\left[V_{i}^{B}\left(\hat{\phi}_{i} \hat{m}_{i}^{i}, \hat{\phi}_{j} \hat{m}_{j}^{i}\right)\right] \\
\text { s.t. } \phi_{i} \hat{m}_{i}^{i}+\phi_{j} \hat{m}_{j}^{i}+X \leq H+\phi_{i} m_{i}^{i}+\phi_{j} m_{j}^{i}+T_{i}
\end{gathered}
$$

where $m_{j}^{i}$ is country i buyer's holding of country j currency; $V_{i}^{B}$ is country i buyer's value function for DM trade; $T_{i}$ is the lump-sum transfer from country i central bank. This CM value function could be simplified as

$$
W_{i}^{B}=U(X)-X+\phi_{i} m_{i}^{i}+\phi_{j} m_{j}^{i}+T_{i}+\max _{\hat{m}_{i}^{i}, \hat{m}_{j}^{i}}\left\{\beta \mathbb{E}\left[V_{i}^{B}\left(\hat{\phi}_{i} \hat{m}_{i}^{i}, \hat{\phi}_{j} \hat{m}_{j}^{i}\right)\right]-\phi_{i} \hat{m}_{i}^{i}-\phi_{j} \hat{m}_{j}^{i}\right\}
$$

\footnotetext{
${ }^{1}$ This is certainly not without loss of generality, as discussed in Geromichalos and Jung (2015)

${ }^{2}$ Here I assume away the possibility that sellers accept both currencies at the same time, for two reasons. First, that doesn't happen very often in reality, given that LC is mostly issued in a single currency. Second, this assumption makes model tractable in the case of indeterminacy. In my model, sellers would choose home currency if both currencies bring the same level of positive profit. In Zhang (2014), accepting home currency doesn't incur additional information cost for seller, so accepting both currencies is possible. In this model, accepting home currency is also costly for international trade, so sellers would choose a single currency for settlement.
} 
With the observation that buyer's value function is linear in his holding of money, further simplify this into

$$
W_{i}^{B}\left(\phi_{i} m_{i}^{i}, \phi_{j} m_{j}^{i}\right)=W_{i}^{B}(0,0)+\phi_{i} m_{i}^{i}+\phi_{j} m_{j}^{i}
$$

For sellers, they don't have any incentive to hold money in CM since the liquidity he would get from bank is irrelevant with his holding of money. So CM value function for seller is constant with respect to his own money holding.

With similar notations, the CM value function for country i investor is

$$
\begin{gathered}
W_{i}^{I}\left(z_{i}\right)=\max _{\hat{z}_{i}, \hat{a}_{i}, H, X} U(X)-H+\beta \mathbb{E}\left[V_{i}^{I}\left(\hat{z}_{i}, \hat{a}_{i}\right)\right] \\
\text { s.t. } \phi_{i} \hat{z}_{i}+X \leq H+\phi_{i} z_{i}+T_{i}
\end{gathered}
$$

where $V_{i}^{I}\left(\hat{m}_{i}, \hat{a}_{i}\right)$ is the value function for investor in financial market, related with his holding of home currency $\left(\hat{z}_{i}\right)$ and trade acceptance $\left(\hat{a}_{i}\right)$ for next period. Similarly, this value function could be simplified into

$$
W_{i}^{I}\left(z_{i}\right)=W_{i}^{I}(0)+\phi_{i} z_{i}
$$

\subsubsection{Terms of trade in DM}

Buyer and seller make a proportional bargaining in DM to determine terms of trade. Buyer's utility maximization problem is

$$
\begin{gathered}
\max _{q, d(m)}\{u(q)-\phi d(m)\} \\
\text { s.t. } \frac{u(q)-\phi d(m)}{\phi d(m)-\frac{c(q)}{\beta}}=\frac{\theta}{1-\theta} \\
d(m) \leq m
\end{gathered}
$$

where $q$ is the amount of differentiated good sellers would produce; $d(m)$ is the amount of fiat money buyers would pay to sellers; $\theta$ is buyer's bargaining power. Since buyers make payment only when q is delivered at the beginning of next period, seller's surplus 
is adjusted by discount factor. The solution is

$$
d(m)= \begin{cases}m^{*} & \text { if } \phi m>\frac{c\left(q^{*}\right)}{\beta} \\ m & \text { if } \phi m \leq \frac{c\left(q^{*}\right)}{\beta}\end{cases}
$$

where $q^{*}$ is the level of consumption that would maximize total surplus such that $\beta u^{\prime}\left(q^{*}\right)=c^{\prime}\left(q^{*}\right) ; m^{*}$ is buyer's payment when total surplus is maximized, so $\phi m^{*}=$ $(1-\theta) u\left(q^{*}\right)+\theta \frac{c\left(q^{*}\right)}{\beta}$. It will become clear in equilibrium that buyer's holding of fiat money would never exceed $m^{*}$, because excessive money doesn't increase his gains from trade, but would incur a loss from inflation. Therefore, buyer's payment to seller is $\phi m=(1-\theta) u(q)+\theta \frac{c(q)}{\beta}$, with $q \leq q^{*}, \beta u^{\prime}\left(q^{*}\right)=c^{\prime}\left(q^{*}\right)$.

\subsubsection{Investor decision in FM}

Country i investor's profit maximization problem in FM is

$$
\begin{gathered}
\max _{a_{i}}\left\{z_{i}+\left(y_{i}-p_{i}\right) a_{i}\right\} \\
\text { s.t. } \quad p_{i} a_{i} \leq z_{i}
\end{gathered}
$$

where $p_{i}$ and $y_{i}$ are nominal price and payoff of trade acceptance issued by country i's banking sector. Notice that investor is risk-neutral since his CM value function is linear in $z$, so he would only want to maximize his expected level of wealth. Individual investor's demand for trade acceptance is

$$
a_{i}= \begin{cases}0 & \text { if } y_{i}<p_{i} \\ z_{i} / p_{i} & \text { if } y_{i} \geq p_{i}\end{cases}
$$

This result is intuitive: if the payoff is lower than cost, investor's demand would be zero. For country i investor, the total demand for trade acceptance is $D=(1-2 \sigma) a_{i}$ - The total payoff of trade acceptance in country i should be equal to buyer's total payment for international trade settled in country i currency, so the total supply of trade acceptance is $S=\frac{s_{i} n_{j i} m_{i}^{j}+\left(1-s_{j}\right) n_{i j} m_{i}^{i}}{y_{i}}$.

At equilibrium, if trade acceptance is attractive to investor, its payoff must be no less than price, so $\frac{y_{i}}{p_{i}}=\frac{s_{i} n_{j i} m_{i}^{j}+\left(1-s_{j}\right) n_{i j} m_{i}^{i}}{(1-2 \sigma) z_{i}} \geq 1$. 


\subsubsection{Financial constraint and seller's decision}

More importantly, the addition of bank and investor imposed financial constraint for monetary equilibrium that allows for international trade. The immediate liquidity provided by bank must be able to cover seller's DM cost. Given a perfect competitive banking sector, zero profit condition holds, so this immediate liquidity is equal to the proceedings from selling trade acceptance, net of banking sector's fixed cost. Consequently, country i seller's gain from international trade settled in home currency is

$$
\pi_{i} \equiv\left[1-\frac{F_{i}}{(1-2 \sigma) \phi_{i} z_{i}}\right]\left(\frac{1}{1+R_{i}}\right) \phi_{i} m_{i}^{j}-c\left(q_{i}^{j}\right)
$$

where $R_{i} \equiv \frac{\phi_{i}}{\beta \hat{\phi}_{i}}-1$ is the nominal interest rate of country i, and $q_{i}^{j}$ is country $j$ buyer's purchase of differentiated good settled in country $i$ currency.

From this result, seller's revenue in DM trade is affected by three factors. First, terms of trade from proportional bargaining, $\phi_{i} m_{i}^{j}$. Second, discount factor of $(1+$ $\left.R_{i}\right)^{-1}$. Finally, financial friction influenced by the fixed cost of banking sector $\left(F_{i}\right)$ and financial market liquidity of $(1-2 \sigma) \phi_{i} z_{i}$. Intuitively, fixed cost is negatively correlated with seller's revenue, while an increase of financial market liquidity could help improve seller's profit from DM trade.

As shown later, inflation has negative impact on these factors at the same time. For terms of trade, higher inflation would reduce buyer's trade volume and real balance holding; for discount factor, it erodes the value of future payment; for financial friction, it tends to depress investor's confidence, thus lowering their purchase of trade acceptance. In short, higher inflation would get amplified by financial market and hugely deteriorate exporter's welfare.

Similarly, country i seller's profit from international trade settled in foreign currency is

$$
\pi_{i}^{*} \equiv\left[1-\frac{F_{j}}{(1-2 \sigma) \phi_{j} z_{j}}\right]\left(\frac{1}{1+R_{j}}\right) \phi_{j} m_{j}^{j}-c\left(q_{j}^{j}\right)
$$


With these in mind, country i sellers choose settlement currency ${ }^{3}$.

$$
\begin{cases}\text { autarky } & \text { if } \max \left\{\pi_{i}, \pi_{i}^{*}\right\}<0 \\ s_{i}=1 & \text { if } \max \left\{\pi_{i}, \pi_{i}^{*}\right\} \geq 0, \pi_{i} \geq \pi_{i}^{*} \\ s_{i}=0 & \text { if } \max \left\{\pi_{i}, \pi_{i}^{*}\right\} \geq 0, \pi_{i}<\pi_{i}^{*}\end{cases}
$$

Finally, currency regime comes from seller's decision. If $\left\{s_{1}, s_{2}\right\}=\{1,0\}$ or $\{0,1\}$, there's a single international currency, which case referred to as hegemony from now; if $\left\{s_{1}, s_{2}\right\}=\{1,1\}$, both currencies become international, and seller would use home currency for trade settlement, which is producer currency pricing (PCP); if $\left\{s_{1}, s_{2}\right\}=$ $\{0,0\}$, there are two international currencies, and international trade is settled by importer's home currency, which is local currency pricing (LCP). Currency regime is summarized in table 2 .

\subsubsection{Optimal choice for buyer and investor}

For buyer and investor, the optimal holding of real balance is available after combining $\mathrm{CM}$ and DM value function. For country i buyer, his DM value function is

$$
V_{i}^{B}=\left(p_{i i}+\left(1-s_{j}\right) p_{i j}\right)\left(u\left(q_{i}^{i}\right)-\phi_{i} m_{i}^{i}\right)+p_{i j} s_{j}\left(u\left(q_{j}^{i}\right)-\phi_{j} m_{j}^{i}\right)+W_{i}^{B}
$$

where $\left(p_{i i}+\left(1-s_{j}\right) p_{i j}\right)\left(u\left(q_{i}^{i}\right)-\phi_{i} m_{i}^{i}\right)$ is country i buyer's expected surplus for DM trade settled in country $i$ currency, while $p_{i j} s_{j}\left(u\left(q_{j}^{i}\right)-\phi_{j} m_{j}^{i}\right)$ is his expected surplus for trade settled in country $j$ currency.

Substitute this into the expression of buyer's CM value function, then his maximization problem becomes

$$
\begin{gathered}
\max _{\hat{m}_{i}^{i}, \hat{m}_{j}^{i}}\left\{\left(\beta \hat{\phi}_{i}-\phi_{i}\right) \hat{m}_{i}^{i}+\beta\left(p_{i i}+\left(1-s_{j}\right) p_{i j}\right) \theta\left[u\left(\hat{q}_{i}^{i}\right)-\frac{c\left(\hat{q}_{i}^{i}\right)}{\beta}\right]\right. \\
\left.+\left(\beta \hat{\phi}_{j}-\phi_{j}\right) \hat{m}_{j}^{i}+\beta s_{j} p_{i j} \theta\left[u\left(\hat{q}_{j}^{i}\right)-\frac{c\left(\hat{q}_{j}^{i}\right)}{\beta}\right]\right\}
\end{gathered}
$$

\footnotetext{
${ }^{3}$ Here I didn't consider the asymmetric case when international trade is profitable for country i seller but not for country $\mathrm{j}$ seller, just for the sake of simplicity. It's quite easy to include that case and related discussion would be straightforward.
} 
Several conventional observation in monetary search model would also apply here. For example, the solution for maximization problem requires $\beta \hat{\phi}_{i}-\phi_{i}<0$ and $m<m^{*}$. The first order condition for home currency is

$$
R_{i}=\left(p_{i i}+\left(1-s_{j}\right) p_{i j}\right)\left[\frac{\theta\left(u^{\prime}\left(q_{i}^{i}\right)-c^{\prime}\left(q_{i}^{i}\right) / \beta\right)}{(1-\theta) u^{\prime}\left(q_{i}^{i}\right)+\theta c^{\prime}\left(q_{i}^{i}\right) / \beta}\right]
$$

This first order condition means buyer's marginal cost of holding money $\left(R_{i}\right)$ must be equal to the expected marginal benefit. Notice that buyer's demand for home currency is positive since his meeting with domestic sellers would always use home currency as medium of exchange. This is not true for foreign currency, which depends on foreign seller's decision.

$$
\begin{cases}q_{j}^{i}=0 & \text { if } s_{j}=0 \\ R_{j}=p_{i j}\left[\frac{\theta\left(u^{\prime}\left(q_{j}^{i}\right)-c^{\prime}\left(q_{j}^{i}\right) / \beta\right)}{(1-\theta) u^{\prime}\left(q_{j}^{i}\right)+\theta c^{\prime}\left(q_{j}^{i}\right) / \beta}\right] & \text { if } s_{j}=1\end{cases}
$$

For simplicity, define $L(q) \equiv \frac{\theta\left(u^{\prime}(q)-c^{\prime}(q) / \beta\right)}{(1-\theta) u^{\prime}(q)+\theta c^{\prime}(q) / \beta}$ as liquidity premium. Apply the same procedure to investor's maximization problem, and combine the first order condition with equilibrium level of $y_{i} / p_{i}$, I could get investor's optimal holding of home currency.

$$
\begin{cases}z_{i}=0 & \text { if }\left\{s_{i}, s_{j}\right\}=\{0,1\} \\ R_{i}=\frac{s_{i} n_{j i} \phi_{i} m_{i}^{j}+\left(1-s_{j}\right) n_{i j} \phi_{i} m_{i}^{i}}{(1-2 \sigma) \phi_{i} z_{i}}-1, & \text { otherwise }\end{cases}
$$

This result is also intuitive: if home currency never became international, investor wouldn't hold any of that; otherwise, investor's marginal cost of holding home currency should be equal to the rate of return from trade acceptance.

Lastly, money market should clear after agents make choice. Consider the case 
when international trade is profitable. $\forall i, j=\{1,2\}, i \neq j$

$$
\begin{cases}\sigma \phi_{i} m_{i}^{i}=\phi_{i} M_{i} & \text { if }\left\{s_{i}, s_{j}\right\}=\{0,1\} \\ \sigma \phi_{i} m_{i}^{i}+(1-2 \sigma) \phi_{i} z_{i}+F_{i}=\phi_{i} M_{i} & \text { if }\left\{s_{i}, s_{j}\right\}=\{0,0\} \\ \sigma \phi_{i} m_{i}^{i}+\sigma \phi_{i} m_{i}^{j}+(1-2 \sigma) \phi_{i} z_{i}+F_{i}=\phi_{i} M_{i} & \text { if }\left\{s_{i}, s_{j}\right\}=\{1,0\},\{1,1\}\end{cases}
$$

For the first case, country i currency remains national, so its demand comes from only domestic buyer. For the second case of LCP, its demand comes from home buyer, home investor, and banking sector. For the last case, home buyer, home investor, foreign buyer, and banking sector would all demand for country i currency.

\subsubsection{Monetary equilibrium of international trade}

With agent's optimal choice, now it's possible to define a stationary monetary equilibrium. My main concern is the emergence of international currency, so I would focus on the equilibrium that allows for international trade.

Definition 1 A stationary monetary equilibrium that allows for international trade is a list of time-invariant values including trade volume $\left\{q_{j}^{i}\right\}_{i, j=1}^{2}$, investor's holding

of real balance $\left\{\phi_{i} z_{i}\right\}_{i=1}^{2}$, and seller's choice of settlement currency $\left\{s_{i}\right\}_{i=1}^{2}$ such that, given other agent's behavior,

1. Seller's choice of $\left\{s_{i}\right\}_{i=1}^{2}$ solves (1);

2. Buyer's choice of $\left\{q_{j}^{i}\right\}_{i, j=1}^{2}$ solves (2)(3);

3. Investor's choice of $\left\{\phi_{i} z_{i}\right\}_{i=1}^{2}$ solves (4);

4. Money market clears so that (5) holds. 


\subsection{Hegemony and incumbency advantage}

Now consider the case of hegemony when country 1 currency becomes international while country 2 currency remains national $\left(s_{1}=1, s_{2}=0\right)$. Could 1 would be referred to as center country while country 2 as peripheral country. Intuitively, country 1 buyer would never hold foreign currency since his home currency is universally acknowledged and appreciated. In contrast, country 2 buyer would hold home currency for domestic trade and foreign currency for international trade. Moreover, the single international currency makes financial market active only in country 1. Consistent with definition 1, equilibrium condition is explicitly shown in appendix. There is incumbency advantage of country 1 in this international monetary system. Due to the economy of scale in banking sector, country 2 currency would never become international without collective action, government promotion, or a sudden shock that drains financial market liquidity in country 1 . This observation is reflected in proposition 1.

Proposition 1 If country 1 currency is the only international currency, an individual seller would never use country 2 currency for international trade settlement.

Proof In this case, country 2 seller couldn't ask country 1 buyer to pay country 2 currency since neither buyer or investor in country 1 holds foreign currency. For country 1 seller, if he accepted country 2 currency for trade settlement, his profit is

$$
\pi_{1}^{*} \leq \epsilon \underbrace{(1-\theta)\left[u\left(q_{2}^{1}\right)-c\left(q_{2}^{1}\right) / \beta\right]}_{\text {DM surplus for seller }}-F_{2},
$$

where $\epsilon$ is the number of seller trying to accept country 2 currency. If $\epsilon$ is not sufficiently large relative to $F_{2}$, seller's profit would be negative thanks to the fixed cost in the banking sector of country 2 .

Notice the difference between this incumbency advantage and the size effect emphasized by classical literature. Previous studies often argued that the size effect of large economy would help lower the transaction cost of its currency in foreign exchange market, therefore justifying its status of international currency. But proposition 1 shows that economy size alone is not enough. Financial development proves 
indispensable.

This situation of hysteresis leaves room for policy intervention. Government could promote the internationalization of its currency by decreasing $F$ through financial reform or deregulation. Another possibility is for central bank to absorb financial friction by becoming market maker. In history, federal reserve took advantage of both options after 1913, and the rise-up of US dollar was largely attributed to that, as vividly described in Eichengreen (2011).

\subsection{Monetary policy and international trade}

With definition 1, the equilibrium condition for hegemony, PCP, and LCP could be outlined, and comparative statics on monetary policy become possible. On the part of domestic trade, monetary policy has uniform effect on agent's welfare level: higher inflation tends to reduce their gains from trade. On the part of investor, it's also easy to show that higher inflation level erodes confidence and drives down financial market liquidity. The effect of monetary policy on international trade, however, differs according to currency regimes, as shown in proposition 2 .

Proposition 2 Under some general assumptions, higher inflation of international currency would hurt whoever used it for trade settlement.

(i) For hegemony, higher inflation of international currency would hurt importer and exporter from both countries, i.e., $\frac{\partial q_{1}^{1}}{\partial R_{1}}<0, \frac{\partial q_{1}^{2}}{\partial R_{1}}<0, \frac{\partial \pi_{1}}{\partial R_{1}}<0, \frac{\partial \pi_{2}^{*}}{\partial R_{1}}<0$.

(ii) For PCP, higher inflation of international currency would hurt home exporter and foreign importer, i.e., $\frac{\partial \pi_{1}}{\partial R_{1}}<0, \frac{\partial q_{1}^{2}}{\partial R_{1}}<0$.

(iii) For LCP, higher inflation of international currency would hurt home importer and foreign exporter, i.e., $\frac{\partial q_{1}^{1}}{\partial R_{1}}<0, \frac{\partial \pi_{2}^{*}}{\partial R_{1}}<0$.

Proof in appendix 
One interesting observation from proposition 2 is the relationship between nominal exchange rate and net export. This model is quite silent on exchange rate partly because, as shown in proposition 1, it's the incumbency advantage and financial development that determines the emergence of international currency. A discussion on monetary policy and international trade, however, necessitates the inclusion of exchange rate. In particular, the possibility of 'beggar thy neighbor' through nominal depreciation would influence the conduct of monetary policy. Now assume Law of One Price (LOP) for numéraire good holds in this model, and nominal exchange rate is $e_{i / j} \equiv \frac{\phi_{j}}{\phi_{i}}$, where $e_{i / j}$ is the nominal exchange rate of country i currency per country $\mathrm{j}$ currency. Given that $\phi_{i}=\left(1+\mu_{i}\right) \hat{\phi}_{i}$ in stationary monetary equilibrium, a higher inflation level of home currency would lead to nominal depreciation, whose effect on international trade differs according to currency regime.

For hegemony, the result is unclear and contingent on parameter value. For PCP, higher inflation and home currency depreciation would hurt home exporter and foreign importer, thus lowering home export and net export, given that home import is insulated from this shock. For LCP, home currency depreciation would hurt home importer and foreign exporter, thus lowering home import and increasing home net export. Therefore, in this model, 'beggar thy neighbor' through nominal depreciation is possible in LCP, impossible in PCP, and uncertain in hegemony. These observations are summarized in table 3 . Of course, the conduct of monetary policy is over-simplified in model. In reality, a sterilized FX intervention could depreciate home currency and stabilize money supply at the same time. A more elaborate model is required for in-depth discussion.

\subsection{Welfare analysis and optimal monetary policy}

A prominent advantage of monetary search model is the tractability of agent's asset holding and welfare level, which is important for the conduct of optimal monetary policy if central bank is assumed to maximize the social welfare of its own country. In this model, social welfare consists of seigniorage revenue, gains from trade, and a loss from banking sector's fixed cost if this country issues international currency. For simplicity, additional welfare gain from consuming numéraire good is omitted. 
If country 1 issues the only international currency, for example, social welfare level at the end of each period is the following.

$$
\begin{aligned}
W_{1}= & \underbrace{\mu_{1} \sigma \phi_{1} m_{1}^{2}}_{\text {Seigniorage revenue }}+\underbrace{n_{11}\left[\beta u\left(q_{1}^{1}\right)-c\left(q_{1}^{1}\right)\right]}_{\text {domestic trade surplus }}+\underbrace{n_{12} \theta\left[\beta u\left(q_{1}^{1}\right)-c\left(q_{1}^{1}\right)\right]}_{\text {importer surplus }} \\
& +\underbrace{n_{21}\left\{\left[1-\frac{F_{1}}{(1-2 \sigma) \phi_{1} z_{1}}\right]\left(\frac{1}{1+R_{1}}\right) \phi_{1} m_{1}^{2}-c\left(q_{1}^{2}\right)\right\}}_{\text {exporter surplus }}-F_{1} \\
W_{2}= & -\mu_{1} \sigma \phi_{1} m_{1}^{2}+n_{22}\left[\beta u\left(q_{2}^{2}\right)-c\left(q_{2}^{2}\right)\right]+n_{21} \theta\left[\beta u\left(q_{1}^{2}\right)-c\left(q_{1}^{2}\right)\right] \\
& +n_{12}\left\{\left[1-\frac{F_{1}}{(1-2 \sigma) \phi_{1} z_{1}}\right]\left(\frac{1}{1+R_{1}}\right) \phi_{1} m_{1}^{1}-c\left(q_{1}^{1}\right)\right\}
\end{aligned}
$$

With similar procedure, the welfare level for PCP and LCP is shown in appendix.

From previous assumptions and proposition 2, each country's gain from international trade is decreasing in the nominal interest rate of international currency. For seigniorage revenue, recall that central bank's lump-sum transfer is only applied to domestic agent, and other agents need to purchase that currency in CM. Therefore, seigniorage revenue is possible only when there's foreign demand for that country's currency. Without loss of generality, assume seigniorage revenue is increasing in the growth rate of money supply, which gives incentive to deviate from Friedman rule.

Seigniorage revenue would cancel out in the summation of each country's welfare, so Friedman rule is optimal for a social planner trying to maximize total welfare. In addition, it's inefficient to issue two international currencies since that would incur fixed cost of banking sector in both countries. Social planner would let a country with lower $F$ issue a single international currency. For each country aimed at maximizing its own welfare, Friedman rule is not optimal if there's foreign demand of its currency, which includes the case of PCP and hegemony when a country issues the only international currency. These observations are summarized in proposition 3.

Proposition 3 In a stationary monetary equilibrium with international trade, Friedman rule of zero nominal interest rate is not always optimal. 
1. For social planner trying to maximize total welfare, Friedman rule is optimal, and countries with higher degree of financial development would issue international currency.

2. For central bank trying to maximize the social welfare of its own country, Friedman rule is not optimal when there's is foreign demand of its currency.

Figure 4 is shows the second case of central bank faced with a trade off between seigniorage revenue and gains from trade. It plots the relationship between nominal interest rate and the welfare level of a country that issues the only international currency. The function form is borrowed from Lagos and Wright (2005) with $u(q)=\ln (q+b)-\ln (q), c(q)=q, b=0.0001$. The rest of parameter value is shown in table 4 . Friedman rule is clearly not optimal, since the welfare level is maximized around $16 \%$ of nominal interest rate. Also, the status of international currency would be lost if nominal interest rate is raised above $25 \%$, putting a limit central bank's conduct of monetary policy, which has been intensively discussed in Zhang (2014).

One interpretation of proposition 3 is to regard international currency as public good, in the spirit of Kindleberger (1986). Center country makes investment in banking sector and financial institution to facilitate trade. Peripheral country takes advantage of international currency as well as the system of payment and settlement. Seigniorage revenue conveys negative externality since center country tends to inflate and overproduce international currency, and that would hurt the rest of world. For a social planner, that externality is internalized and canceled out, retaining Friedman rule as the optimal monetary policy.

\section{Discussion of related topic}

\section{$5.1 \quad$ Size effect}

Classical and recent literature uniformly favored large economy as provider of international currency due to size effect. For example, Devereux and Shi (2013) built a 
DSGE model for quantitative analysis, and concluded that large country is in a good position to provide international currency, since large trade volume would reduce transaction cost in FX market. In what follows I would use a numerical example to re-evaluate this issue.

In my model, economy size is approximated by national population, i.e., the total number of buyer, seller, and investor. A change in population would, according to matching function, directly influence the number and probability of the meeting between buyer and seller, thus affecting equilibrium outcome. Figure 5 shows the relationship for center country's population and its optimal nominal interest rate. Parameter value and function forms are identical to those in figure 4. Center country's population is ranged from 0.1 to 10 , while peripheral country's population stays at 1. A hump-shape is surprising at first sight, but the composition of center country's welfare in figure 6 demystifies everything. In essence, size effect alters the degree of trade-off between seigniorage revenue and gains from trade. For a large economy, gains from domestic trade dominate its total welfare, so higher inflation is not a good choice. Similarly, gains from international trade compromise the biggest part of welfare for a small open economy, reducing the attractiveness of reaping seigniorage revenue. It's therefore reasonable to think of figure 5 as a continuation of proposition 3 in exploration of center country's optimal monetary policy. Size effect is crucial here not because of its absolute value, but in affecting the desirability of seigniorage revenue: if gains from trade loom larger and larger from size effect, convergence to Friedman rule becomes a better choice. In other words, it is the structure of economy, the share of trade in its total welfare, that determines whether a country is qualified as natural provider of international currency.

To summarize, hegemony is reasonable for a unipolar world dominated by economic superpower, while multiple international currencies make sense in a multipolar world with evenly distributed economy size.

\subsection{Economic integration and currency union}

Notwithstanding its illustrative nature, this model sheds some light on economic integration and currency union. Recall that $\alpha$ is the probability for buyer to stay 
at home, so greater value of $(1-\alpha)$ means higher degree of economic integration. Figure 7 and 8 capture this effect when a single international currency is issued by center country, where openness of an economy is equal to $(1-\alpha)$. All parameter values and function forms are identical to those in figure 4, with the only exception of $\alpha$. Clearly, international trade is not a win-win game in this case, partly since it doesn't whether buyer is matched with home or foreign seller: economic integration here implies a higher chance for buyer to meet foreign seller, but the total gains from trade should be roughly constant. For a social planner adhering to Friedman rule, this kind of economic integration makes little difference.

The winner and loser in this process of integration, once again, results from the externality of seigniorage revenue. Center country's welfare improvement in figure 7 is mainly attributed to a fast increase of seigniorage revenue, which would hurt peripheral country's welfare in figure 8 . Such observation revives the classical discussion of currency union in Mundell (1961) that argues for the priority of factor mobility and economic integration. The numerical result in this section provides another perspective: a hegemony system of single international currency would damage peripheral country's gain from international trade. The alternative of multiple international currencies or currency union is justified in promoting social welfare. Of course, the determinants of currency union include many other factors not explicitly modeled here, such as institution cost, economy structure, and exchange rate system.

\subsection{Capital account liberalization}

This model assumed capital control in financial market and mainly focused on international trade. One interesting question is what will happen if investors are allowed to participate in the financial market of foreign countries. In other words, what's impact of capital account liberalization on international monetary system?

In model, this hardly makes any difference. International trade would not be affected since it doesn't matter whether trade is financed by home or foreign investors. From condition (4), financial market liquidity is the same as before, determined by trade volume and nominal interest rate. Welfare level and optimal monetary policy might change since a currency could be demanded by foreign investors, but the net 
effect is ambiguous. One argument in favor of capital account liberalization might be the effect on financial market development: reform and deregulation could help lower the fixed cost in banking sector, thus improving welfare level.

In reality, capital account liberalization is central to policy discussion. On one hand, free capital flow certainly helps accelerate the process of currency internationalization, since financial transaction has the lion's share of international currency use. On the other hand, the risk and uncertainty involved in opening capital account should never be trifled with. Foreign demand of international currency would complicate central bank's conduct of monetary policy, and external shock is also going to be easily transmitted to domestic economy. Overall, a better model tailored to such discussion directs future research.

\section{Concluding remarks}

China has been trying to internationalize RMB since great recession, and several measures are taken to accelerate this process, including currency swap agreement, offshore market development, cross-border trade settlement, and capital account liberalization. Among these, trade settlement is a natural starting point given China's leading role in international trade of merchandise. In contrast to traditional view of thick market externality and natural monopoly, recent findings highlight the importance of a deep and liquid financial market. To provide micro-foundation for such observation, I incorporated financial frictions into the monetary search model in Zhang (2014). This illustrative model also emphasized government's role in taking initiative to foster market, and explored the conduct of monetary policy in different regimes. Future research could extend to 3-country or N-country model to account for the emergence of vehicle currency. Modeling financial market in a more meaningful way is also desirable to discuss asset pricing as well as the impact of capital account liberalization.

China's recent campaign of helping RMB join SDR basket reaffirmed its grand plan of financial reform and deregulation, although the outcome of such bold action remains uncertain. A monetary system with multiple international currencies is beneficial to United States, who has been long accused of exorbitant privilege, as well 
as peripheral countries often criticized for excessive reserve accumulation. Whether $\mathrm{RMB}$ is a qualified candidate in this race to new world, we shall wait and see.

\section{References}

Asmundson, I., Dorsey, T., Khachatryan, A., Niculcea, I., and Saito, M. (2011). Trade and trade finance in the 2008-09 financial crisis.

Bacchetta, P. and Van Wincoop, E. (2005). A theory of the currency denomination of international trade. Journal of International Economics, 67(2):295-319.

Bénassy-Quéré, A. (2015). The euro as an international currency. Handbook of the Economics of European Integration.

Berentsen, A., Camera, G., and Waller, C. (2007). Money, credit and banking. Journal of Economic Theory, 135(1):171-195.

Broz, J. L. (1997). The international origins of the Federal Reserve System. Cornell University Press.

Committee on the Global Financial System (2014). Trade finance: developments and issues. Bank for International Settlements.

Devereux, M. B. and Shi, S. (2013). Vehilcle currency. International Economic Review, 54(1):97-133.

Diamond, D. W. and Dybvig, P. H. (1983). Bank runs, deposit insurance, and liquidity. The journal of political economy, pages 401-419.

Eichengreen, B. (2011). Exorbitant Privilege: The rise and fall of the Dollar and the Future of the International Monetary System. Oxford University Press.

Eichengreen, B. and Flandreau, M. (2012). The federal reserve, the bank of england, and the rise of the dollar as an international currency, 1914-1939. Open Economies Review, 23(1):57-87. 
Geromichalos, A. and Jung, K. M. (2015). An over-the-counter approach to forex market.

Goldberg, L. S. and Tille, C. (2008). Vehicle currency use in international trade. Journal of International Economics, 76(2):177-192.

Goldberg, L. S. and Tille, C. (2013). A bargaining theory of trade invoicing and pricing.

ICC Banking Commission (2014). Rethinking Trade Finance 2014: An ICC Global Survey.

Ito, H. and Chinn, M. (2013). The rise of the redback and chinas capital account liberalization: an empirical analysis on the determinants of invoicing currencies.

Kindleberger, C. P. (1986). International public goods without international government. The American Economic Review, pages 1-13.

Krugman, P. R. (1979). Vehicle currencies and the structure of international exchange.

Lagos, R. and Wright, R. (2005). A unified framework for monetary theory and policy analysis. Journal of Political Economy, 113(3).

Matsuyama, K., Kiyotaki, N., and Matsui, A. (1993). Toward a theory of international currency. The Review of Economic Studies, 60(2):283-307.

Mundell, R. (2012). The case for a world currency. Journal of Policy Modeling, 34(4):568-578.

Mundell, R. A. (1961). A theory of optimum currency areas. The American Economic Review, pages 657-665.

Niepmann, F. and Schmidt-Eisenlohr, T. (2014). International trade, risk and the role of banks.

Rey, H. (2001). International trade and currency exchange. The Review of Economic Studies, 68(2):443-464. 
Trejos, A. and Wright, R. (1996). Searchtheoretic models of international currency. Federal Reserve Bank of St. Louis Review, 78(May/June 1996).

Zhang, C. (2014). An information-based theory of international currency. Journal of International Economics, 93(2):286-301.

Zhou, X. (2009). The reform of the international monetary system. China finance, $7: 8-9$. 


\section{Appendix}

\section{Equilibrium condition of different currency regimes}

According to definition 1, the equilibrium condition for country 1 currency to emerge as the single international currency is the following.

For buyer

$$
\left\{\begin{array}{l}
R_{1}=\left(p_{11}+p_{12}\right) L\left(q_{1}^{1}\right)=p_{21} L\left(q_{1}^{2}\right) \\
R_{2}=p_{22} L\left(q_{2}^{2}\right)
\end{array}\right.
$$

For seller

$$
\left\{\begin{array}{l}
\pi_{1}=\left[1-\frac{F_{1}}{(1-2 \sigma) \phi_{1} z_{1}}\right]\left(\frac{1}{1+R_{1}}\right) \phi_{1} m_{1}^{2}-c\left(q_{1}^{2}\right)>0 \\
\pi_{2}^{*}=\left[1-\frac{F_{1}}{(1-2 \sigma) \phi_{1} z_{1}}\right]\left(\frac{1}{1+R_{1}}\right) \phi_{1} m_{1}^{1}-c\left(q_{1}^{1}\right)>0
\end{array}\right.
$$

For investor

$$
R_{1}=\frac{n_{1,2} \phi_{1} m_{1}^{1}+n_{2,1} \phi_{1} m_{1}^{2}}{(1-2 \sigma) \phi_{1} z_{1}}-1
$$

For money market

$$
\left\{\begin{array}{l}
\sigma \phi_{1} m_{1}^{1}+\sigma \phi_{1} m_{1}^{2}+(1-2 \sigma) \phi_{1} z_{1}+F_{1}=\phi_{1} M_{1} \\
\sigma \phi_{2} m_{2}^{2}=\phi_{2} M_{2}
\end{array}\right.
$$

If equations (1.1)-(1.8) are satisfied at the same time, country 1 currency would emerge as the only international currency. Similarly, the equilibrium condition for $\mathrm{PCP}$ is the following.

For buyer

$$
\left\{\begin{array}{l}
R_{1}=p_{11} L\left(q_{1}^{1}\right)=p_{21} L\left(q_{1}^{2}\right) \\
R_{2}=p_{12} L\left(q_{2}^{1}\right)=p_{22} L\left(q_{2}^{2}\right)
\end{array}\right.
$$


For seller

$$
\left\{\begin{array}{l}
\pi_{1}>0, \pi_{1}>\pi_{1}^{*} \\
\pi_{2}>0, \pi_{2}>\pi_{2}^{*}
\end{array}\right.
$$

For investor

$$
\left\{\begin{array}{l}
R_{1}=\frac{n_{21} \phi_{1} q_{1}^{2}}{(1-2 \sigma) \phi_{1} z_{1}}-1 \\
R_{2}=\frac{n_{12} \phi_{2} q_{2}^{1}}{(1-2 \sigma) \phi_{2} z_{2}}-1
\end{array}\right.
$$

For money market

$$
\left\{\begin{array}{l}
\sigma \phi_{1} m_{1}^{1}+\sigma \phi_{1} m_{1}^{2}+(1-2 \sigma) \phi_{1} z_{1}+F_{1}=\phi_{1} M_{1} \\
\sigma \phi_{2} m_{2}^{2}+\sigma \phi_{2} m_{2}^{1}+(1-2 \sigma) \phi_{2} z_{2}+F_{2}=\phi_{2} M_{2}
\end{array}\right.
$$

For LCP, equilibrium condition is the following.

For buyer

$$
\left\{\begin{array}{l}
R_{1}=\left(p_{11}+p_{12}\right) L\left(q_{1}^{1}\right) \\
R_{2}=\left(p_{22}+p_{21}\right) L\left(q_{2}^{2}\right)
\end{array}\right.
$$

For seller

$$
\left\{\begin{array}{l}
\pi_{1}^{*}>0 \\
\pi_{2}^{*}>0
\end{array}\right.
$$

For investor

$$
\left\{\begin{array}{l}
R_{1}=\frac{n_{12} \phi_{1} q_{1}^{1}}{(1-2 \sigma) \phi_{1} z_{1}}-1 \\
R_{2}=\frac{n_{21} \phi_{2} q_{2}^{2}}{(1-2 \sigma) \phi_{2} z_{2}}-1
\end{array}\right.
$$

For money market

$$
\left\{\begin{array}{l}
\sigma \phi_{1} m_{1}^{1}+(1-2 \sigma) \phi_{1} z_{1}+F_{1}=\phi_{1} M_{1} \\
\sigma \phi_{2} m_{2}^{2}+(1-2 \sigma) \phi_{2} z_{2}+F_{2}=\phi_{2} M_{2}
\end{array}\right.
$$




\section{Proof of proposition 2}

Most of this proof is straightforward except the part of exporter's gain from international trade, which requires additional assumption on function form.

Lemma 1 If exporter's financial loss is more sensitive than DM cost function in response to interest rate shock, i.e., $\left(\epsilon_{f}+\epsilon_{c}\right)>0$, exporter's gain from international trade is decreasing in nominal interest rate, i.e., $\frac{\partial \pi}{\partial R}<0$.

Proof Let $\beta^{E} \equiv\left(1-\frac{F}{(1-2 \sigma) \phi z}\right)(1+R)^{-1}$ denote the effective discount factor for seller. Without loss of generality, assume $\beta^{E}<\beta$ so that financial friction would reduce seller's gain from trade. Therefore, $\left(\beta-\beta^{E}\right)>0$ is a measure of seller's financial loss. Combine the expression of buyer's payment in DM and seller's profit in section (3.2.4), I could get

$$
\pi=\beta^{E}(1-\theta)\left[u(q)-\frac{c(q)}{\beta}\right]-\frac{1}{\beta}\left(\beta-\beta^{E}\right) c(q) .
$$

Given that $\frac{\partial \phi z}{\partial R}<0$, it's easy to find that $\frac{\partial \beta^{E}}{\partial R}<0$. With the previous condition in proportional bargaining, $q<q^{*}, u^{\prime}(q *)=\frac{c^{\prime}\left(q^{*}\right)}{\beta}, u^{\prime}<0, c^{\prime}>0$, the first item is decreased in $R$.

For the second item, differentiate with respect to $R$, I could get $\frac{c f}{\beta R}\left(\epsilon_{f}+\epsilon_{c}\right)$, where $f \equiv\left(\beta-\beta_{E}\right)$ captures the degree of seller's financial loss, $\epsilon_{f} \equiv \frac{\partial f}{\partial R} \frac{R}{f}$ is the elasticity of financial loss on nominal interest rate. Similarly, $\epsilon_{c}$ is the elasticity of seller's DM cost in response to interest rate shock. Obviously, $\epsilon_{f}>0, \epsilon_{c}<0$. A sufficient condition for $\frac{\partial \pi}{\partial R}<0$ is $\epsilon_{f}+\epsilon_{c}>0$. Therefore, as long as financial loss is more sensitive to the change of nominal interest rate, higher inflation level would decrease exporter's gain from international trade.

Another helpful observation is the property of buyer's liquidity premium. Recall its definition.

$$
L(q) \equiv \frac{\theta\left(u^{\prime}(q)-\frac{c^{\prime}(q)}{\beta}\right)}{(1-\theta) u^{\prime}(q)+\theta \frac{c^{\prime}(q)}{\beta}}
$$


Take differentiation with respect to q, I could get the following result.

$$
L^{\prime}(q)=\frac{\theta}{\beta}\left[(1-\theta) u^{\prime}(q)+\frac{\theta}{\beta} c^{\prime}(q)\right]^{-2}\left(u^{\prime \prime} c^{\prime}-u^{\prime} c^{\prime \prime}\right)
$$

With previous assumption on function form, $u^{\prime}>0, c^{\prime}>0, u^{\prime \prime}<0, c^{\prime \prime}>0$, it's obvious that $L^{\prime}(q)<0$, so buyer's liquidity premium is decreasing in his trade volume. After these preparations, now it's easy to prove proposition 2 .

\section{Proof of Proposition 2}

On the part of exporters, assume $\epsilon_{f}+\epsilon_{c}>0$ always holds.

For single international currency

$$
\left\{\begin{array} { l } 
{ \frac { \partial q _ { 1 } ^ { 1 } } { \partial R _ { 1 } } = ( ( p _ { 1 1 } + p _ { 1 2 } ) L ^ { \prime } ( q _ { 1 } ^ { 1 } ) ) ^ { - 1 } < 0 } \\
{ \frac { \partial q _ { 1 } ^ { 2 } } { \partial R _ { 1 } } = ( p _ { 2 1 } L ^ { \prime } ( q _ { 1 } ^ { 2 } ) ) ^ { - 1 } < 0 }
\end{array} \quad \left\{\begin{array}{l}
\frac{\partial \pi_{1}}{\partial R_{1}}<0 \\
\frac{\partial \pi_{2}^{*}}{\partial R_{1}}<0
\end{array}\right.\right.
$$

For $P C P$

$$
\left\{\begin{array} { l } 
{ \frac { \partial q _ { 2 } ^ { 1 } } { \partial R _ { 1 } } = 0 } \\
{ \frac { \partial q _ { 1 } ^ { 2 } } { \partial R _ { 1 } } = ( p _ { 2 1 } L ^ { \prime } ( q _ { 1 } ^ { 2 } ) ) ^ { - 1 } < 0 }
\end{array} \quad \left\{\begin{array}{l}
\frac{\partial \pi_{1}}{\partial R_{1}}<0 \\
\frac{\partial \pi_{2}}{\partial R_{1}}=0
\end{array}\right.\right.
$$

For $L C P$

$$
\left\{\begin{array} { l l } 
{ \frac { \partial q _ { 2 } ^ { 1 } } { \partial R _ { 1 } } = ( ( p _ { 1 1 } + p _ { 1 2 } ) L ^ { \prime } ( q _ { 1 } ^ { 1 } ) ) ^ { - 1 } < 0 } \\
{ \frac { \partial q _ { 2 } ^ { 2 } } { \partial R _ { 1 } } = 0 }
\end{array} \quad \left\{\begin{array}{l}
\frac{\partial \pi_{1}^{*}}{\partial R_{1}}=0 \\
\frac{\partial \pi_{2}^{*}}{\partial R_{1}}<0
\end{array}\right.\right.
$$




\section{Welfare level}

For PCP, the welfare level is the following.

$$
\begin{aligned}
W_{1}= & \underbrace{\mu_{1} \sigma \phi_{1} m_{1}^{2}-\mu_{2} \sigma \phi_{2} m_{2}^{1}}_{\text {Seigniorage revenue }}+\underbrace{n_{11}\left[\beta u\left(q_{1}^{1}\right)-c\left(q_{1}^{1}\right)\right]}_{\text {domestic trade surplus }}+\underbrace{n_{12} \theta\left[\beta u\left(q_{2}^{1}\right)-c\left(q_{2}^{1}\right)\right]}_{\text {importer surplus }} \\
& +\underbrace{n_{21}\left\{\left[1-\frac{F_{1}}{(1-2 \sigma) \phi_{1} z_{1}}\right]\left(\frac{1}{1+R_{1}}\right) \phi_{1} m_{1}^{2}-c\left(q_{1}^{2}\right)\right\}}_{\text {exporter surplus }}-F_{1} \\
W_{2}= & \mu_{2} \sigma \phi_{2} m_{2}^{1}-\mu_{1} \sigma \phi_{1} m_{1}^{2}+n_{22}\left[\beta u\left(q_{2}^{2}\right)-c\left(q_{2}^{2}\right)\right]+n_{21} \theta\left[\beta u\left(q_{1}^{2}\right)-c\left(q_{1}^{2}\right)\right] \\
& +n_{12}\left\{\left[1-\frac{F_{2}}{(1-2 \sigma) \phi_{2} z_{2}}\right]\left(\frac{1}{1+R_{2}}\right) \phi_{2} m_{2}^{1}-c\left(q_{2}^{1}\right)\right\}-F_{2}
\end{aligned}
$$

For LCP, welfare level is the following.

$$
\begin{aligned}
W_{1}= & \underbrace{n_{11}\left[\beta u\left(q_{1}^{1}\right)-c\left(q_{1}^{1}\right)\right]}_{\text {domestic trade surplus }}+\underbrace{n_{12} \theta\left[\beta u\left(q_{1}^{1}\right)-c\left(q_{1}^{1}\right)\right]}_{\text {importer surplus }} \\
& +\underbrace{n_{21}\left\{\left[1-\frac{F_{2}}{(1-2 \sigma) \phi_{2} z_{2}}\right]\left(\frac{1}{1+R_{2}}\right) \phi_{2} m_{2}^{2}-c\left(q_{2}^{2}\right)\right\}}_{\text {exporter surplus }}-F_{1} \\
W_{2}= & n_{22}\left[\beta u\left(q_{2}^{2}\right)-c\left(q_{2}^{2}\right)\right]+n_{21} \theta\left[\beta u\left(q_{2}^{2}\right)-c\left(q_{2}^{2}\right)\right] \\
& +n_{12}\left\{\left[1-\frac{F_{1}}{(1-2 \sigma) \phi_{1} z_{1}}\right]\left(\frac{1}{1+R_{1}}\right) \phi_{2} m_{1}^{1}-c\left(q_{1}^{1}\right)\right\}-F_{2}
\end{aligned}
$$


Table 1 International function of money

\begin{tabular}{lll}
\hline \hline & For government & For private agent \\
Store of value & international reserve & investment instrument \\
Medium of exchange & FX intervention & international trade settlement \\
Unit of account & currency anchor & denominate financial asset \\
\hline
\end{tabular}

Table 2 Currency regime

\begin{tabular}{lll}
\hline \hline Regime & Seller's choice & Description \\
\hline Hegemony & $\left\{s_{i}, s_{j}\right\}=\{1,0\}$ & Country i currency is international \\
& & Country j currency is national \\
PCP & $\left\{s_{1}, s_{2}\right\}=\{1,1\}$ & Two international currencies \\
& & Trade settled in seller's home currency \\
& $\left\{s_{1}, s_{2}\right\}=\{0,0\}$ & Two international currencies \\
& & Trade settled in buyer's home currency \\
\hline
\end{tabular}


Table 3 Monetary policy and international trade

\begin{tabular}{lccc}
\hline \hline & Hegemony & PCP & LCP \\
home importer & $\frac{\partial q_{1}^{1}}{\partial R_{1}}<0$ & $\frac{\partial q_{2}^{1}}{\partial R_{1}}=0$ & $\frac{\partial q_{1}^{1}}{\partial R_{1}}<0$ \\
home exporter & $\frac{\partial \pi_{1}}{\partial R_{1}}<0$ & $\frac{\partial \pi_{1}}{\partial R_{1}}<0$ & $\frac{\partial \pi_{1}^{*}}{\partial R_{1}}=0$ \\
foreign importer & $\frac{\partial q_{1}^{2}}{\partial R_{1}}<0$ & $\frac{\partial q_{1}^{2}}{\partial R_{1}}<0$ & $\frac{\partial q_{2}^{2}}{\partial R_{1}}=0$ \\
foreign exporter & $\frac{\partial \pi_{2}^{*}}{\partial R_{1}}<0$ & $\frac{\partial \pi_{2}}{\partial R_{1}}=0$ & $\frac{\partial \pi_{2}^{*}}{\partial R_{1}}<0$ \\
\hline home net export & $?$ & $\frac{\partial N X_{1}}{\partial R_{1}}<0$ & $\frac{\partial N X_{1}}{\partial R_{1}}>0$ \\
foreign net export & $?$ & $\frac{\partial N X_{2}}{\partial R_{1}}>0$ & $\frac{\partial N X_{2}}{\partial R_{1}}<0$ \\
\hline
\end{tabular}

Notes: Country 1 is regarded as home country. In the first column, country 1 currency emerged as the single international currency. For the second column, international trade is settled by seller's home currency. For the last column, international trade is settled by buyer's home currency. 
Table 4 Parameter choice

\begin{tabular}{lll}
\hline \hline Parameter & Value & Description \\
\hline $1-\alpha$ & 0.5 & degree of economic integration \\
$\beta$ & 0.966 & discount factor \\
$\sigma$ & 0.5 & share of buyer \\
$\theta$ & 0.5 & buyer's bargaining power \\
$F$ & 0.01 & fixed cost of banking sector \\
\hline
\end{tabular}


Figure 1 Market share of financing agreement

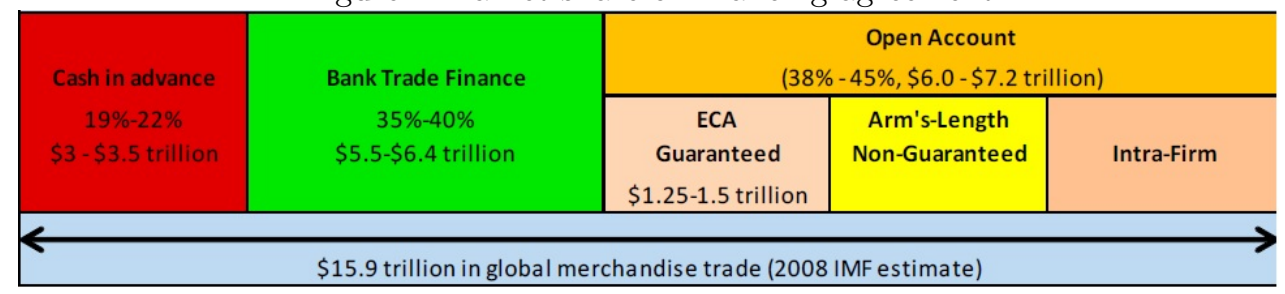

Source: Asmundson et al. (2011)

Figure 2 Mechanism of LC
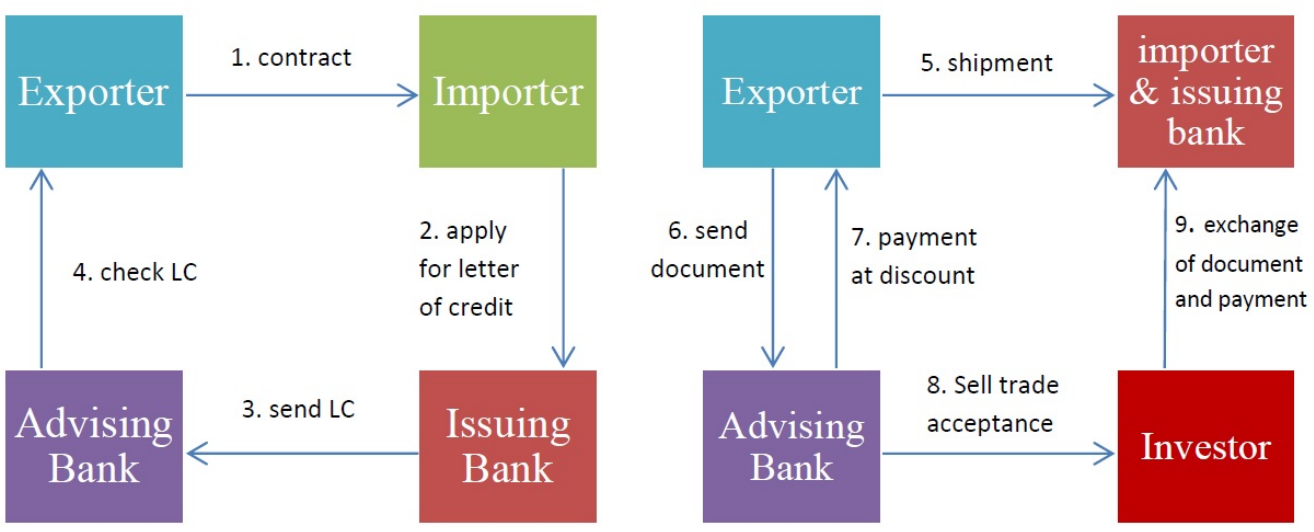

Source: adapted from Niepmann and Schmidt-Eisenlohr (2014)

Figure 3 Timeline of model

Centralized Market (CM) Decentralized Market (DM) Financial Market (FM)

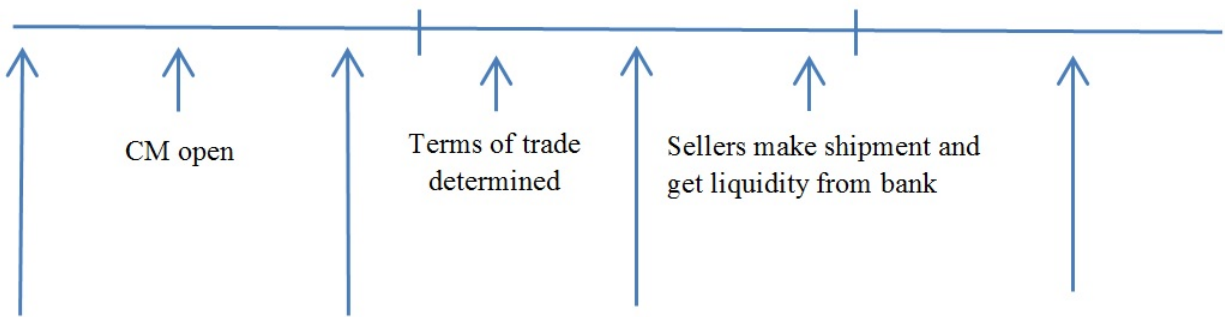

Buyers pay and get shipment
Agents adjust money holding
Banks issue LC

Banks sell trade acceptance to investor 
Figure 4 Optimal monetary policy

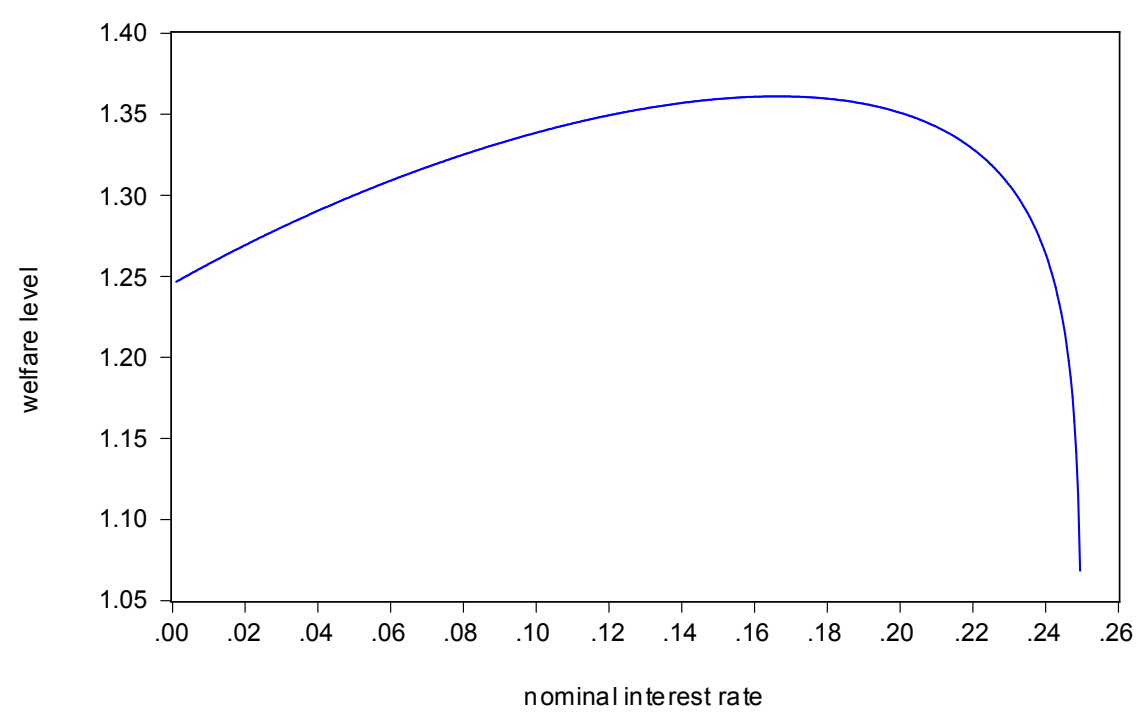

Figure 5 Size effect

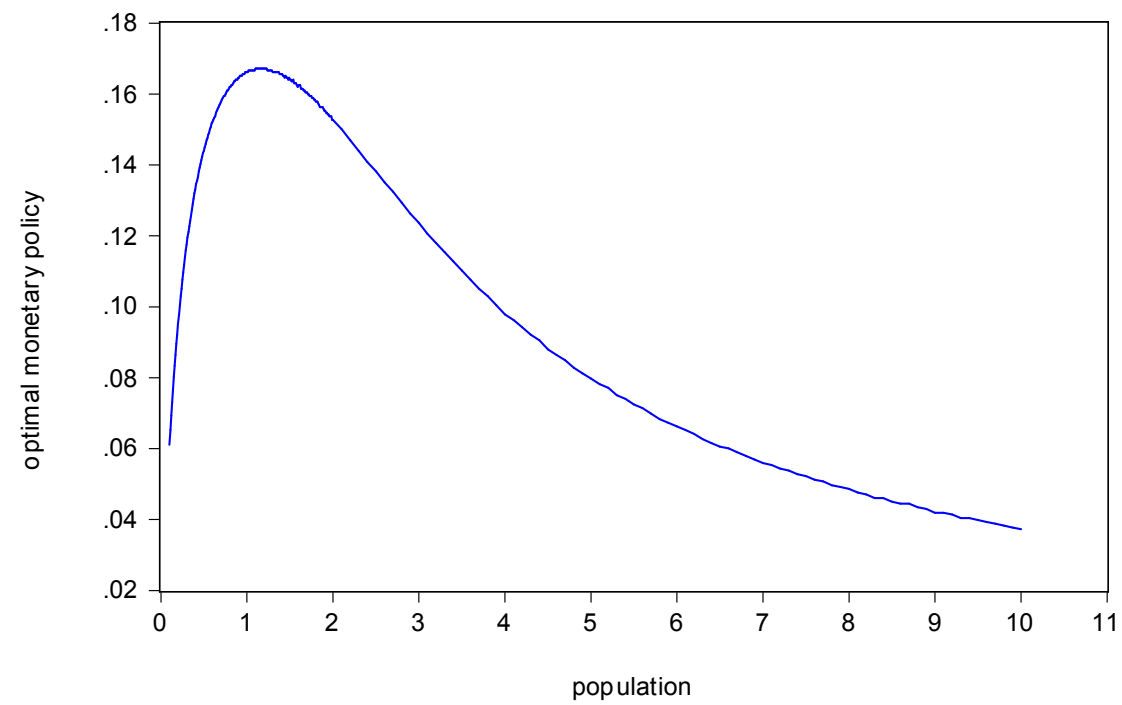


Figure 6 Composition of welfare

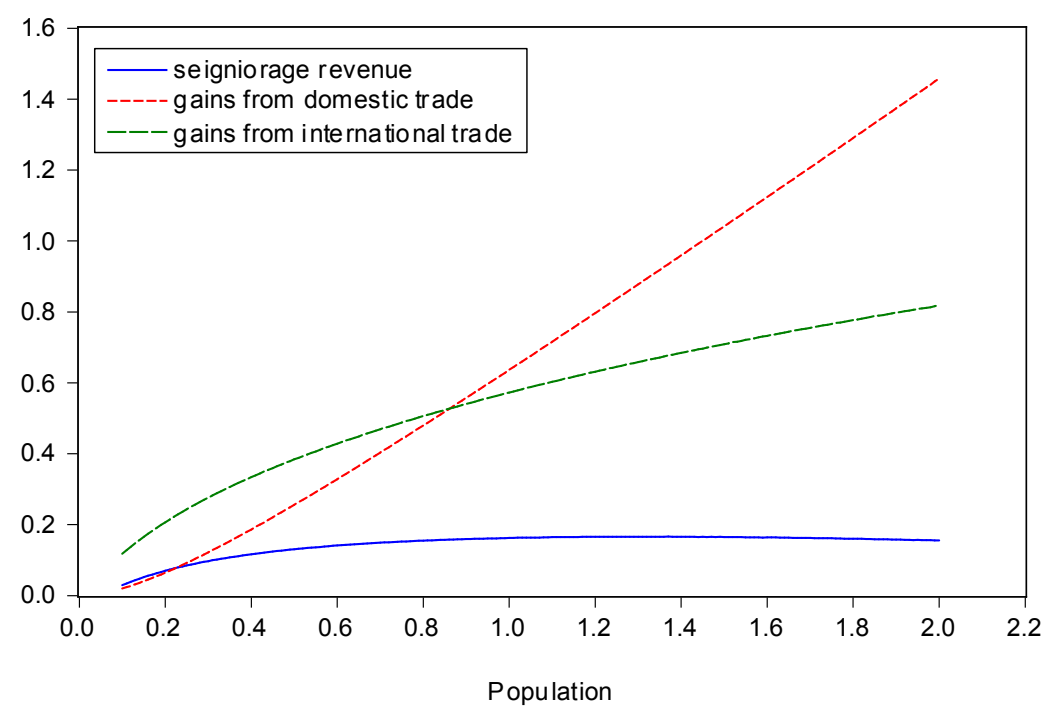

Figure 7 Economic integration: center country

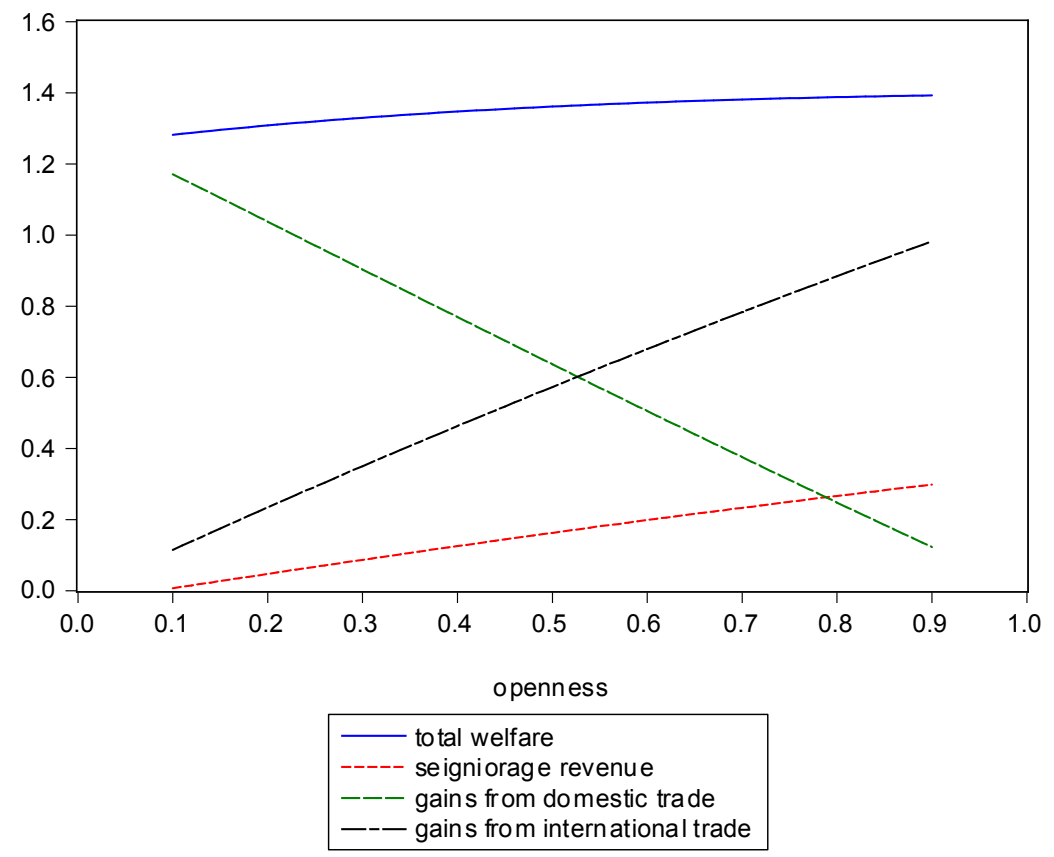


Figure 8 Economic integration: peripheral country

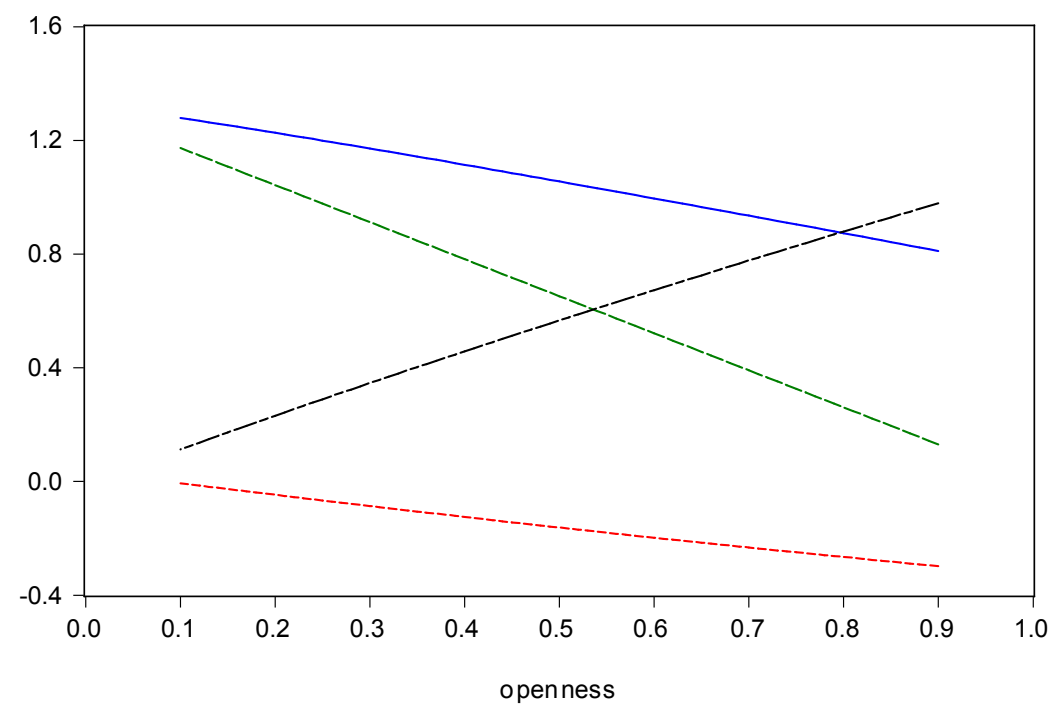

- total we lfare

----- seigniorage revenue

- - - gains from domestic tra de

_-_ gains from in te rnational trade 